\title{
Farmers' Perceptions of Finger Millet Production Constraints, Varietal Preferences and Their Implications to Finger Millet Breeding in Uganda
}

\author{
Lawrence Owere $^{1,2}$, Pangirayi Tongoona ${ }^{1}$, John Derera $^{1} \&$ Nelson Wanyera ${ }^{2}$ \\ ${ }^{1}$ African Centre for Crop Improvement, School of Agricultural, Earth and Environmental Sciences, College of \\ Agriculture, Engineering and Science, University of KwaZulu Natal, Scottsville, Pietermaritzburg, Republic of \\ South Africa \\ ${ }^{2}$ National Semi-Arid Resources Research Institute, Serere, Private Bag, Soroti, Uganda \\ Correspondence: Lawrence Owere, African Centre for Crop Improvement, School of Agricultural, Earth and \\ Environmental Sciences, College of Agriculture, Engineering and Science, University of KwaZulu Natal, Private \\ Bag X01, Scottsville, Pietermaritzburg 3209, Republic of South Africa. Tel: 256-772-836-847. E-mail: \\ owerepaya@yahoo.com; labowere@gmail.com
}

Received: February 8, 2014 Accepted: August 14, 2014 Online Published: November 15, 2014

doi:10.5539/jas.v6n12p126 URL: http://dx.doi.org/10.5539/jas.v6n12p126

\begin{abstract}
Finger millet is an important food security and cash crop in Uganda but its production is constrained by a number of factors. However, information on farmers' perceptions of constraints and varietal preferences is limited. A study was conducted to; identify varieties and varietal preferences in finger millet, and assess farmers' constraints to finger millet production and coping mechanisms. The study involved a participatory rural appraisal, and a survey. Farmers identified the major constraint as high labour requirements especially for weeding since over $95 \%$ of the farmers used broadcasting as a method of planting. Other constraints that occurred across all the districts were blast disease and low yielding cultivars. Farmers also reported to have developed some coping mechanisms to counter the constraints. In terms of preference for new cultivars, farmers preferred high grain yield, brown seed colour, compact head shape, tolerance to blast disease, high tillering ability, moderate plant height $(1 \pm 0.2 \mathrm{~m})$, early maturity, tolerance to shattering and ease of threshing without compromising other preferred attributes. The study further revealed that a considerable proportion of the farmers had limited or no knowledge on finger millet blast disease, its causes and mechanisms of coping. Farmers also reported that blast disease symptoms in all locations were on the increase over the years and pointed out the most susceptible and tolerant cultivars. These findings therefore, present an urgent need for information sharing with farmers and other agricultural development partners, and continuous development of blast resistant cultivars with farmer preferred attributes.
\end{abstract}

Keywords: blast disease, finger millet, participatory rural appraisal, varietal preferences

\section{Introduction}

Finger millet is an important staple food crop in Uganda where it is believed to have originated, but its production is still low. Tenywa et al. (1999) reported farmer grain yield of 400-800 $\mathrm{kg} \mathrm{ha}^{-1}$ in Uganda which is very low compared to $2,500 \mathrm{~kg} \mathrm{ha}^{-1}$ attainable in research conditions. The low yields are a manifestation of the low attention and research input accorded to the crop (Bedis, Ganvir, \& Pantil, 2006; Fakrudin, Kulkani, Shashidhar, \& Hittalmani, 2004). Use of poor unimproved landraces susceptible to finger millet blast disease and drought are the other major contributors to low yields in Uganda. A study by Wanyera (2007b) identified finger millet blast disease as one of the highest priority constraints to finger millet production in Uganda affecting the crop at all stages of growth and affecting most of the landraces and other genotypes. The study also reported that damage by blast in finger millet resulted in major yield losses.

In Uganda over $80 \%$ of the population is involved in subsistence agriculture with the most important cereals being maize, finger millet and sorghum in that order (Wanyera, 2007a). These farmers contribute over $90 \%$ of finger millet production (Ministry of Agriculture Animal Industry and Fisheries [MAAIF], 2008) in harsh environments that make most of them stick to their landraces and reluctant to adopt improved cultivars (Okwadi, 
2007). According to Wanyera (2007a), some improved cultivars have been released but adoption by the small-scale farmers, the main growers of finger millet is low. Kidoido, Kasenge, Mbowa, Tenywa, and Nyende (2002) suggests a number of reasons for this scenario, principal among them is the failure of breeders to involve and incorporate farmers' concerns in their cultivars development. The outcomes have been new cultivars with limited or no consideration to special preferences of the target farmers in the marginal environments (Banziger \& Cooper, 2001; Thiele, Gardner, Torrez, \& Gabriel, 1997). To enhance adoption, breeding will have to be based on clear understanding of farmers' preferential trait attributes in new cultivars and appropriate solutions to their specific and unique constraints. One of the options suggested by Banziger, Edmeades, Beck, and Bellon (2000) is participatory variety development to capture perspectives and ensure ownership of the new cultivars. This therefore makes participatory breeding approach a way of knowing these farmers' experiences so as to include them in the breeding objectives (Islam, Salam, Bhuiyan, Rahman, \& Gregorio, 2008).

\subsection{Participatory Plant Breeding}

Participatory plant breeding has been suggested as an effective alternative to formal plant breeding as a strategy for achieving productivity gains under low input conditions. In recent years, there has been an increasing shift in paradigm that the farmers' participation in technology development increases the likelihood of technology adoption (Islam et al., 2008). Participatory plant breeding has many advantages, among them increased and more stable productivity, better understanding of farmers' varietal criteria and faster release and adoption of varieties. Participatory crop improvement involves farmers directly in the process of variety improvement and testing at an earlier stage than in conventional breeding process. It is designed to better incorporate perspectives of end users than formal plant breeding, reach resource poor farmers, breed for high-stress and diverse conditions and incorporate wide variation in traits for specific farmer preferences (Dorward, Craufurd, Marfo, Dogbe, \& Bam, 2007).

In order to estimate the potential adoption of the new varieties and facilitate overall evaluation of potential benefits of developing new varieties, an assessment of attributes of finger millet varieties preferred by farmers and socio-economic environment under which the farmers operate is an important starting point. Acceptability of agricultural technologies by farmers depends on how well researchers have identified farmers' objectives and constraints (Upton, 1987). As breeders involve farmers as participants, they will learn more about the most important criteria of farmers' preferences in cultivars; this encourages the use of locally adapted cultivars and makes the breeders less dependent of foreign materials (Daniel, Parveviet, Almekinders, \& Thiele, 2007). Participatory research also allows incorporation of farmers' indigenous technical knowledge, identification of farmers' criteria and priorities and definition of research agenda (Chambers, 1994). Participatory rural appraisal (PRA) tools are usually applied to determine farmers' perceptions and preferences (Kidoido et al., 2002), it involves local people in collecting and analyzing information, allows seeking of insights about their local and actual conditions and fosters dialogue between scientists and farmers. By integrating farmers' concerns and conditions into agricultural research, research will develop technologies that become widely adopted, resulting in more productive, stable, equitable and sustainable agricultural systems.

\subsection{Participatory Rural Appraisal}

Participatory rural appraisal has been previously conducted on finger millet in Uganda (Okwadi, 2007; Kidoido et al., 2002; Tenywa et al., 1999) none of the reports however, pointed to specific farmer preferences in a blast resistant, high yielding finger millet variety. The use of blast resistant finger millet cultivars therefore, might be the most effective blast control measure to the small-scale farmers in marginal areas since it is compatible with their low-input farming practices. This suggests a need to urgently develop blast resistant cultivars with farmer preferred attributes to overcome this major production constraint as this would enhance acceptance and adoption of such varieties by farmers. To achieve this, the first step was to carry out a participatory rural appraisal and a survey among selected famers and farmers' groups in some of the major growing districts with the following objectives: (i) to identify finger millet varieties grown by farmers, (ii) to identify trait preferences in finger millet, and (iii) to assess farmers' constraints to finger millet production and coping mechanisms.

\section{Materials and Methods}

The study was divided into two components: i) a participatory rural appraisal was conducted to reveal the varieties farmers were growing, preferences in a finger millet cultivars, production constraints and knowledge on blast disease and management, and ii) a survey was also conducted with individual farmers to confirm the PRA findings. 


\subsection{Sampling Procedure and Data Collection}

A multi-stage sampling procedure was used to select the sites for the study that represent diverse ecological and socio-economic environments in the finger millet growing areas of Uganda. Selection was based on relative importance of finger millet in the agro-ecological zone, major constraints and severity of finger millet blast disease. A preparatory survey was conducted before the PRA in all the study areas, in which a team visited each of the selected district agricultural officers, and from these meetings, sub-counties that produce the most finger millet were identified and selected. The extension officers from the sub-counties were requested to identify farmer groups to participate in the PRA exercise and select individual farmers for the survey. Additional relevant data were also collected from other partners in the agricultural sector with specific interest on finger millet.

The participatory rural appraisal (PRA) and survey were conducted in three selected districts of eastern Uganda, namely; Kumi, Bukedea and Kaberamaido (Figure 1). Focus group discussions were held with four farmer groups, one each for Kumi and Bukedea; whereas two were held in Kaberamaido. These districts were selected because finger millet is one of the most important cereals and staple crop. The discussions were to determine the major crops grown, finger millet varieties, main constraints to finger millet production and identify preferences for new finger millet varieties. The focus group discussion was conducted using a checklist and the major crops and constraints were subsequently ranked using pair-wise ranking method. The current varieties and trait preference were also ranked but according to frequencies of respondents. A semi-structured questionnaire was used for the survey to supplement the findings from the focus group discussions. The survey was conducted with 15 individual farmers each from both Kumi and Bukedea, and 30 from Kaberamaido. The survey focused particularly on finger millet farmers who grow the crop every year. A total of 149 farmers participated in the focus group discussions and the numbers ranged from $30-46$ in each group. There were 33 farmers in Kumi, 40 in Bukedea and 76 in Kaberamaido groups. For the individual household survey, there were sixty farmers involved of whom 27 where female and 33 were males or $45 \%$ and $55 \%$ respectively. The districts are shown in Figure 1. The coordinates for the districts are as follows: Kumi $\left(1^{\circ} 30^{\prime} \mathrm{N}, 33^{\circ} 57^{\prime} \mathrm{E}\right)$, Bukedea $\left(1^{\circ} 21^{\prime} \mathrm{N}, 34^{\circ} 4^{\prime} \mathrm{E}\right)$ and Kaberamaido $\left(1^{\circ} 47^{\prime} \mathrm{N}, 33^{\circ} 9^{\prime} \mathrm{E}\right)$. 


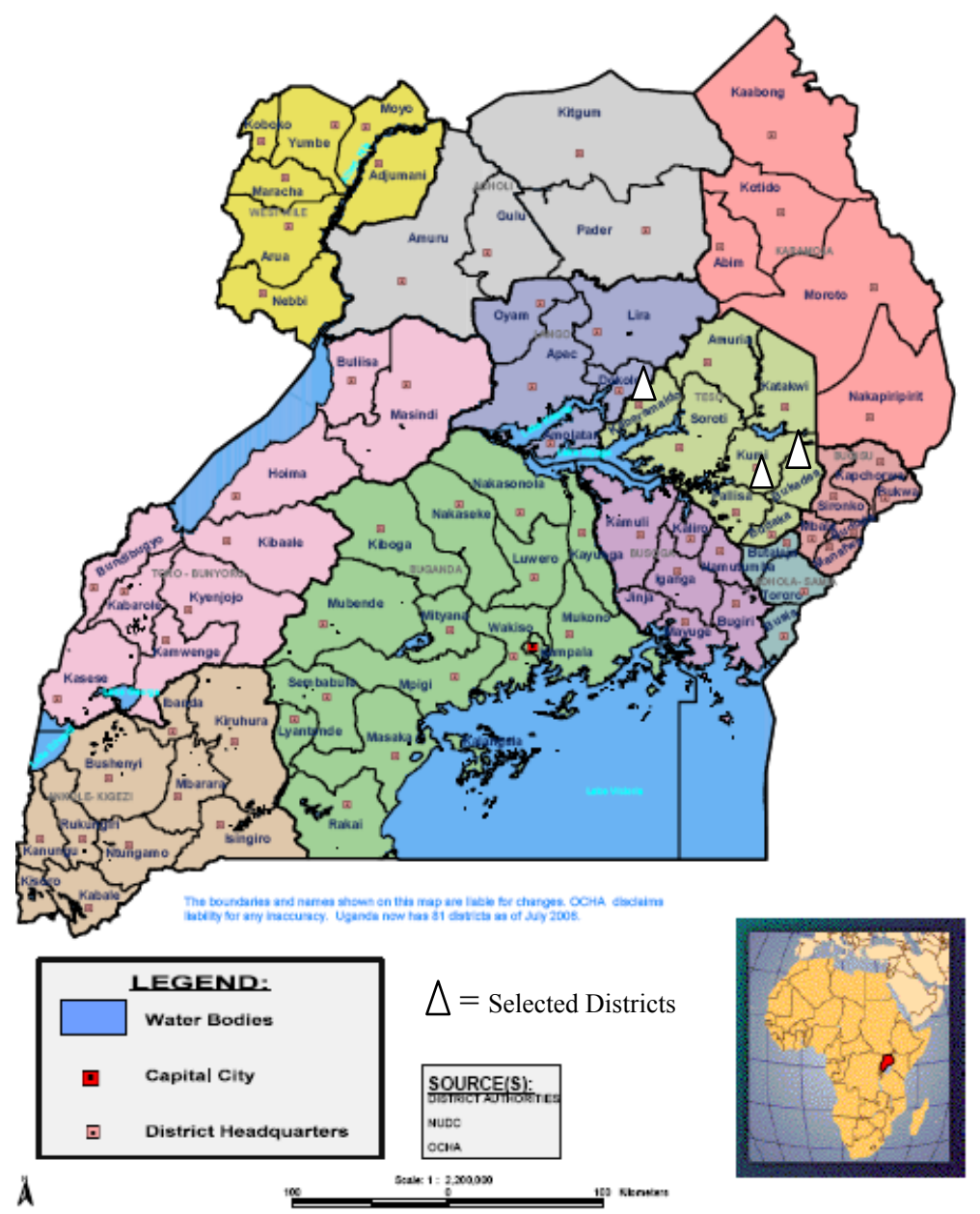

Figure 1. Map of Uganda showing the selected districts for the study. Map adapted from: United Nations Office for the Coordination of Humanitarian Affairs

\subsection{Data Analysis}

The data generated were analysed using descriptive statistics to characterize and summarise the farmers' responses from all the study sites in Statistical Package for Social Scientists (SPSS) version 20 (SPSS, 2011).

\section{Results}

\subsection{Major Crops Grown}

The major crops grown in the three districts are indicated in Table 1. In Kumi and Bukedea, finger millet was grown mainly during the first rainy season (March - July), whereas, in Kaberamaido many farmers grew it in both seasons since both rain seasons were said to be stable, and finger millet is the major food crop. Finger millet also ranked higher in Kaberamaido and Bukedea than Kumi, as these areas received reliable rainfall in both seasons and the yields were considerably higher in both seasons. In Kaberamaido, during the first rains both groups reported finger millet as the most important crop and was their main food crop, however, in the second rains maize seemed to be the major cereal probably because of the higher labour requirements associated with finger millet production. 
Table 1. Major crops grown in the different districts and seasons ranked in order of importance

\begin{tabular}{|c|c|c|c|c|c|c|c|c|}
\hline \multirow{3}{*}{ Crop } & \multirow{2}{*}{\multicolumn{2}{|c|}{$\frac{\text { Kumi }}{\text { Akukurantu farmers' group }}$}} & \multirow{2}{*}{\multicolumn{2}{|c|}{$\frac{\text { Bukedea }}{\text { Nyakoi farmers' group }}$}} & \multicolumn{4}{|c|}{ Kaberamaido } \\
\hline & & & & & \multicolumn{2}{|c|}{ Ajuko farmers' group } & \multicolumn{2}{|c|}{ Awasi farmers' group } \\
\hline & Score & Rank & Score & Rank & Score & Rank & Score & Rank \\
\hline \multicolumn{9}{|l|}{ Season 1} \\
\hline Groundnuts & 07 & 1 & 09 & 2 & 01 & 8 & 01 & 8 \\
\hline Cassava & 05 & 2 & 06 & 4 & 05 & 4 & 05 & 3 \\
\hline Sweet potatoes & 05 & 3 & 04 & 7 & - & - & 04 & 5 \\
\hline Green grams & 04 & 4 & 05 & 5 & - & - & - & - \\
\hline Cowpeas & 03 & 5 & 02 & 10 & - & - & - & - \\
\hline Sorghum & 02 & 6 & 03 & 8 & 02 & 7 & 02 & 7 \\
\hline Finger millet & 02 & 7 & 08 & 3 & 08 & 1 & 08 & 1 \\
\hline Maize & 00 & 8 & 10 & 1 & 06 & 3 & 05 & 4 \\
\hline Beans & - & - & 04 & 6 & 03 & 6 & - & - \\
\hline Paddy rice & - & - & 03 & 9 & - & - & - & - \\
\hline Bambara nuts & - & - & 01 & 11 & - & - & - & - \\
\hline Sesame & - & - & - & - & 07 & 2 & 07 & 2 \\
\hline Sunflower & - & - & - & - & 04 & 5 & 03 & 6 \\
\hline Soybeans & - & - & - & - & 00 & 9 & 01 & 9 \\
\hline \multicolumn{9}{|l|}{ Season 2} \\
\hline Groundnuts & 05 & 3 & - & - & - & - & - & - \\
\hline Cassava & 07 & 1 & 05 & 2 & - & - & 03 & 7 \\
\hline Sweet potatoes & 05 & 2 & 02 & 7 & - & - & - & - \\
\hline Green grams & 02 & 6 & 03 & 5 & - & - & - & - \\
\hline Cowpeas & 03 & 5 & 04 & 4 & - & - & 03 & 5 \\
\hline Sorghum & 04 & 4 & 05 & 3 & - & - & 06 & 3 \\
\hline Finger millet & & & 00 & 8 & 03 & 2 & 03 & 6 \\
\hline Maize & 01 & 8 & 06 & 1 & 03 & 1 & 06 & 2 \\
\hline Pearl millet & 01 & 7 & - & - & - & - & - & - \\
\hline Beans & - & - & 03 & 6 & 01 & 5 & 07 & 1 \\
\hline Sesame & - & - & - & - & 01 & 4 & - & - \\
\hline Sunflower & - & - & - & - & 02 & 3 & 05 & 4 \\
\hline Soybeans & - & - & - & - & - & - & 01 & 9 \\
\hline Cotton & - & - & - & - & - & - & 02 & 8 \\
\hline
\end{tabular}

The scores were obtained from pair-wise ranking and is equivalent to the frequency of the crop in column and row representing the crop. Low score $=$ high ranking indicating crop is less preferred. In case of a tied score, voting was carried out to rank the respective crops.

In Kumi, farmers' preference to grow finger millet in the first rains was due to adequate moisture/precipitation during the season, ease of land preparation after the dry season (December - March), and higher yields obtained during the first rains compared to the second rains. Tradition was also noted to account for non-growing of finger millet during the second rains and high labour requirements. It was also established that during the first rains the crops escaped damage by grass hoppers, web worms, shoot fly and aphids which are highly prevalent during the second rains. Farmers in Kaberamaido also indicated higher rains during the March - July season, but rainfall 
was equally adequate during the second season. Ease of working used fields from the preceding seasons prior to the dry season, and well filled grains for the first rains were also reported. In Bukedea district, adequate rains, ease of land preparation, low weed prevalence, early maturity due to adequate moisture and low pest risk were the reasons for preference of growing finger millet during the first rains. Some farmers also reported less Striga severity during the first rainy season.

\subsection{Farmers' Preference for Improvement}

Table 2 shows a list of farmers' preferences in a finger millet variety as ranked by the farmer groups. Some few farmers indicated that some of the improved varieties did not have good taste and aroma in food and/or could not make quality brew. All the groups however, concurred that there was need for improvement in the current cultivars. The major areas of improvement included; high grain yield, tolerance to blast disease, high tillering ability, plant height, early maturity, tolerance to shattering and ease of threshing without compromising the attributes preferred in their landraces.

Table 2. Farmers preference for improvement - ranked by percentage

\begin{tabular}{|c|c|c|c|c|c|c|c|c|}
\hline \multirow{3}{*}{ Variety characteristic } & \multirow{2}{*}{\multicolumn{2}{|c|}{$\begin{array}{c}\text { Kumi } \\
\begin{array}{c}\text { Akukurantu farmers' } \\
\text { group }(n=33)\end{array}\end{array}$}} & \multirow{2}{*}{\multicolumn{2}{|c|}{$\begin{array}{c}\text { Bukedea } \\
\text { Nyakoi farmers' } \\
\text { group }(n=40)\end{array}$}} & \multicolumn{4}{|c|}{ Kaberamaido } \\
\hline & & & & & \multicolumn{2}{|c|}{$\begin{array}{l}\text { Ajuko farmers' } \\
\text { group }(n=30)\end{array}$} & \multicolumn{2}{|c|}{$\begin{array}{l}\text { Awasi farmers' group } \\
(\mathrm{n}=46)\end{array}$} \\
\hline & $\begin{array}{l}\text { Frequency } \\
(\%)\end{array}$ & Rank & $\begin{array}{c}\text { Frequency } \\
(\%)\end{array}$ & Rank & $\begin{array}{c}\text { Frequency } \\
(\%)\end{array}$ & Rank & $\begin{array}{c}\text { Frequency } \\
(\%)\end{array}$ & Rank \\
\hline Large head size & 100.0 & 1 & 100.0 & 1 & - & - & 80.4 & 4 \\
\hline High grain yield & 100.0 & 1 & 100.0 & 1 & 100.0 & 1 & 100.0 & 1 \\
\hline Large grain size & 84.9 & 3 & - & - & - & - & - & - \\
\hline $\begin{array}{l}\text { Brown }- \text { reddish } \\
\text { brown grain colour }\end{array}$ & 66.6 & 4 & 47.5 & 6 & - & - & 30.4 & 7 \\
\hline Higher grain weight & 63.6 & 5 & - & - & - & - & & - \\
\hline Disease tolerance & 60.6 & 6 & 62.5 & 3 & 40.0 & 8 & 80.4 & 4 \\
\hline Compact head shape & 54.6 & 7 & 27.5 & 8 & 83.3 & 3 & 80.4 & 4 \\
\hline $\begin{array}{l}\text { Ease of harvest and } \\
\text { threshing }\end{array}$ & 51.5 & 8 & 40.0 & 7 & 43.3 & 7 & - & - \\
\hline Early maturity & 48.5 & 9 & - & - & 93.3 & 2 & - & - \\
\hline Tolerance to lodging & 39.4 & 10 & - & - & - & - & - & - \\
\hline Tolerance to shattering & 36.4 & 11 & 50.0 & 5 & - & - & 47.8 & 5 \\
\hline $\begin{array}{l}\text { Drought and heat } \\
\text { tolerance }\end{array}$ & 30.3 & 12 & 70.0 & 2 & - & - & 89.1 & 2 \\
\hline Good aroma and taste & 27.3 & 13 & - & - & 63.3 & 4 & - & - \\
\hline Pest resistance & - & - & 57.5 & 4 & - & - & - & - \\
\hline High tillering ability & - & - & 27.5 & 8 & - & - & 87.0 & 3 \\
\hline Quality brew & - & - & 27.5 & 8 & 83.3 & 3 & 30.4 & 7 \\
\hline $\begin{array}{l}\text { Medium plant height } \\
(1 \pm 1.2 \mathrm{~m})\end{array}$ & - & - & - & - & 60.0 & 5 & - & - \\
\hline High marketability & - & - & - & - & 50.0 & 6 & - & - \\
\hline $\begin{array}{l}\text { Deep green colour of } \\
\text { leaves }\end{array}$ & - & - & - & - & - & - & 37.0 & 6 \\
\hline
\end{tabular}

- denotes characteristic not reported.

\subsection{Major Finger Millet Varieties Grown and Associated Attributes}

The varieties most preferred were Eserait and Etiyo in Kumi, Etiyo and Pese 1 in Bukedea, and Otunduru in Kaberamaido. Farmer groups also listed important advantages and disadvantages of the various varieties grown 
(Table 3). It was found that the varieties differed from the different districts, and this mainly depended on distance from one district to another. Bukedea being close to Kumi had similar varieties, that is, Etiyo and Omududu, where as Kaberamaido which is far from these two districts had completely different varieties. For the two groups in Kaberamaido, most of the varieties grown were also similar. This observation could be an indication that the varieties in far off areas have been evolving independently with no or limited mixes, and limited movement of the varieties. Among the farmers' groups, improved varieties: Pese 1 and Seremi 2 were prevalent in Bukedea and Kumi only, whereas no improved material was reported in Kaberamaido. This could be due to close proximity of the two districts to Serere research institute compared to Kaberamaido and need for up-scaling dissemination activities to all finger millet growing areas.

Table 3. Major attributes of finger millet cultivars grown in the districts of Kumi, Bukedea and Kaberamaido of eastern Uganda

\begin{tabular}{|c|c|c|c|c|c|c|c|c|c|c|c|c|c|c|}
\hline \multirow[b]{2}{*}{ Positive trait attribute } & \multicolumn{14}{|c|}{ Variety and ranking of the varieties for the different trait attributes } \\
\hline & 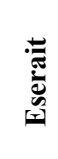 & 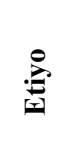 & Е & $\stackrel{\sim}{\ddot{\Xi}}$ & $\begin{array}{l}\overline{0} \\
\tilde{z} \\
\tilde{z}\end{array}$ & $\begin{array}{l}\text { ¿्ँ } \\
\text { ठै }\end{array}$ & 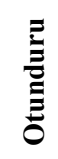 & & 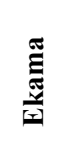 & 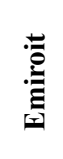 & 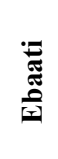 & 䓪 & 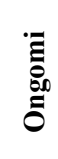 & 苛 \\
\hline Large head size & - & 1 & 2 & 3 & 1 & - & 1 & 2 & - & - & - & - & - & - \\
\hline High grain yield & 2 & 2 & 3 & 3 & 2 & 2 & 1 & 2 & 3 & 2 & 4 & 3 & 3 & 1 \\
\hline Large grain size & 1 & 5 & 1 & 2 & 1 & 1 & 1 & 3 & 4 & 3 & 1 & - & 1 & 1 \\
\hline Brown - reddish brown seed colour & 1 & 1 & 5 & 1 & 2 & 5 & 1 & 4 & 4 & 5 & 1 & 4 & 2 & 2 \\
\hline Higher grain weight & - & - & - & 2 & - & - & 1 & - & - & - & - & - & - & - \\
\hline Disease tolerance & - & - & - & 2 & 3 & - & 1 & - & - & - & - & - & - & - \\
\hline Compact head shape & 2 & 2 & 5 & 2 & 4 & 5 & 1 & 3 & 4 & 5 & 1 & 2 & 2 & 1 \\
\hline Ease of harvest and threshing & - & - & - & 1 & - & - & - & 4 & - & - & - & - & - & 4 \\
\hline Early maturity & 2 & 2 & 3 & 1 & $3 / 4$ & 4 & 5 & 2 & 1 & 4 & 3 & 1 & 2 & 3 \\
\hline Tolerance to lodging & - & - & - & 1 & 3 & - & - & - & - & - & - & - & - & - \\
\hline Tolerance to shattering & - & - & - & - & - & - & 1 & - & - & - & - & - & - & - \\
\hline Drought and heat tolerance & - & - & - & (1) & - & - & 1 & - & - & 5 & 4 & - & - & - \\
\hline Good aroma and taste & - & 2 & - & 2 & - & - & 1 & 4 & - & - & - & 3 & - & - \\
\hline Pest resistance & - & - & - & - & - & - & - & - & - & - & - & -- & - & - \\
\hline Plant height & 2 & 3 & 5 & 1 & 2 & 2 & 4 & 1 & 4 & 1 & 1 & 4 & 3 & 4 \\
\hline Quality brew & - & - & - & - & 4 & - & 1 & 3 & 3 & - & - & - & 4 & 1 \\
\hline High marketability & - & 1 & 4 & 1 & - & - & - & 1 & - & - & - & - & - & - \\
\hline High tillering ability & - & - & - & - & - & - & - & - & - & - & - & - & - & - \\
\hline Greenness & & - & - & - & - & - & - & - & - & - & - & - & - & - \\
\hline Long storage life & - & - & - & - & - & - & 1 & - & - & - & - & - & - & 1 \\
\hline
\end{tabular}

Ranking used is $1-5$; with 1 most desirable attribute of the trait and 5 least desirable attribute of the trait. Whereas - denotes attributes not reported.

The farmer groups rated the importance of finger millet traits on a scale of 1-5 and the results are summarised in Table 3. High yields, brown seed colour and medium height were preferred across all the three districts by all the farmer groups. For the main varieties in the different districts; Eserait was liked mainly for large grain size, reddish-brown colour, early maturity, compact head shape and medium plant height. Etiyo was liked for large head size, reddish brown colour, high marketability, compact head shape, early maturity, and good aroma and taste in food. Otunduru on the other hand was preferred for large head size, high grain yield, large grain size, brown seed colour, blast disease tolerance, compact head shape, tolerance to shattering, long storage life, brewing quality, and good taste and aroma. Otunduru was however, noted to be late maturing and with high plant 
height which made harvesting more difficult especially for women who mainly harvest the crop, meanwhile for Etiyo the grains were reported to be of small size and the plants were shorter making harvesting difficult.

\subsection{Constraints to Finger Millet Production in Eastern Uganda and Coping Mechanisms}

The major constraint reported across the three districts (Table 4) was the high labour requirements especially for weeding since $95 \%$ of all the farmers involved used broadcasting as a means of planting. Other constraints that occurred across all the districts were; blast disease and low yielding cultivars currently used by farmers. The other constraints depended on the farmer groups from the different districts, for instance, insect pests were reported in Kumi and Kaberamaido groups but not in Bukedea, drought was reported in Bukedea and one of the groups in Kaberamaido, and declining soil fertility was also reported in Kumi and one of the groups of Kaberamaido but not in Bukedea. Farmers reported to have developed some coping mechanisms/strategies (Table 5) against bird damage, declining soil fertility, drought and land shortage but none for blast disease management and lack of improved seed. For bird damage farmers reported scarring, use of scare crows and planting when birds seemed to be in their breeding seasons somewhere else. This was particularly reported for the voracious Quelea quelea whose absence was presumed to coincide with the breeding seasons probably in the swamps, rivers and lake shores. This was based on personal experiences of the farmers. For fertility, most farmers reported use of manure and rotation; whereas, to mitigate land shortage, most farmers practiced intercropping and land hire.

Table 4. Major production constraints ranked in order of importance across districts

\begin{tabular}{|c|c|c|c|c|c|c|c|c|}
\hline \multirow{3}{*}{ Constraint } & \multirow{2}{*}{\multicolumn{2}{|c|}{$\begin{array}{c}\text { Kumi } \\
\text { Akukuruantu } \\
\text { farmers' group }\end{array}$}} & \multirow{2}{*}{\multicolumn{2}{|c|}{$\begin{array}{c}\text { Bukedea } \\
\begin{array}{c}\text { Nyakoi farmers' } \\
\text { group }\end{array}\end{array}$}} & \multicolumn{4}{|c|}{ Kaberamaido } \\
\hline & & & & & \multicolumn{2}{|c|}{$\begin{array}{c}\text { Ajuko farmers' } \\
\text { group }\end{array}$} & \multicolumn{2}{|c|}{$\begin{array}{c}\text { Awasi farmers' } \\
\text { group }\end{array}$} \\
\hline & Score & Rank & Score & Rank & Score & Rank & Score & Rank \\
\hline High labour cost & 05 & 1 & 04 & 1 & 06 & 1 & 02 & 1 \\
\hline Insect pests & 04 & 2 & - & - & 00 & 7 & - & 3 \\
\hline Birds & 04 & 3 & - & - & - & - & 01 & - \\
\hline Blast disease & 03 & 4 & 03 & 4 & 02 & 5 & 02 & 2 \\
\hline Striga & 02 & 5 & 01 & 6 & - & - & - & - \\
\hline Declining soil fertility & 02 & 6 & - & - & 05 & 2 & - & - \\
\hline Low yielding varieties & 01 & 7 & 03 & 3 & 04 & 3 & 01 & 4 \\
\hline Drought & - & - & 03 & 2 & 03 & 4 & - & - \\
\hline Land shortage & - & - & 01 & 5 & - & - & - & - \\
\hline Striga & - & - & - & - & - & - & - & - \\
\hline Thefts & - & - & - & - & 01 & 6 & - & - \\
\hline
\end{tabular}

The scores were obtained from pair-wise ranking and is equivalent to the frequency of the crop in column and row representing the crop. Low score $=$ high ranking indicating crop is less preferred. In case of a tied score, voting was carried out to rank the respective crops. 
Table 5. Coping mechanisms for major production constraints

\begin{tabular}{|c|c|c|}
\hline Problem & Coping mechanism & Percentage of responses \\
\hline \multirow{4}{*}{ High labour costs } & -Hire of casual labour & 91 \\
\hline & -Reduction in acreage & 65 \\
\hline & -Row planting & 5 \\
\hline & -Use of previously used field & 56 \\
\hline Insect pests & -None & 100 \\
\hline \multirow{2}{*}{ Bird damage } & -Scarring birds & 44 \\
\hline & -Planting to escape peak population & 62 \\
\hline Blast disease & -None & 100 \\
\hline Low yielding varieties & -Use of improved varieties & 8 \\
\hline \multirow{2}{*}{ Drought } & -Planting short duration varieties & 43 \\
\hline & -Early planting & 62 \\
\hline \multirow{3}{*}{ Striga weed } & -Growing sweet potatoes and legumes & 43 \\
\hline & -Use of crop rotation & \multirow{2}{*}{$\begin{array}{l}54 \\
34\end{array}$} \\
\hline & -Use of intercropping & \\
\hline \multirow{2}{*}{ Land shortage } & -Use of intercropping & 86 \\
\hline & -Land hire & 15 \\
\hline \multirow{3}{*}{ Declining fertility } & -Use of organic manures & 73 \\
\hline & -Crop rotation & 68 \\
\hline & -Use of inorganic fertilizers & 6 \\
\hline \multirow{2}{*}{ Thefts } & -Early harvest & 38 \\
\hline & -Storage in the house & 64 \\
\hline
\end{tabular}

\subsection{Farmers Knowledge on Blast Disease}

After a comprehensive description of blast disease and its effects on finger millet by the team, majority of the farmers recognised the disease but associated it to other causes like witch-craft and drought and had no local name for it, only a very small fraction were aware of the disease and had a name for it. In Kumi and Bukedea it was called ejetele (chaffy or dry heads) whereas there was no name given to it in Kaberamaido. On the occurrence of blast disease symptoms farmers in all locations reported that symptoms were on the increase over the years and pointed out the most susceptible and tolerant cultivars. Farmers in Kumi pointed out that only Seremi 2 was tolerant while in Kaberamaido, Otunduru was the most tolerant cultivar. It was noted in Kumi and Bukedea that Pese 1 which was very tolerant then, is currently exhibiting higher incidences and severity of the disease than previously. Farmers also reported that susceptibility was higher in open headed cultivars compared to fisted/compact headed cultivars. Cause and spread of the disease was not known among the farmers/farmers' groups; creating a serious lack of awareness of the pathogen, pathogen development and spread and therefore control mechanism.

\subsection{Sources of Information}

The farmers who participated in the PRA reported several sources of information including: community/neighbours, Non-Governmental Organisations (NGOs), research organisations, government extension and universities as shown in Table 6. Community and farmer-to-farmer information dissemination was the most commonly used and therefore needed to be strengthened and integrated with the other sources reported by the different groups. The NGOs tended to operate in localised areas, and in their respective areas of operation they were reported as one of the main sources of information. For instance; FAO, TPO, AFRICARE and CCF operated in Kaberamaido but not in Kumi and Bukedea, whereas CIP operated only in Kumi as UNDP and P'KWII operated only in Bukedea among the PRA districts. The government agencies that is, NARO and NAADS were reported in all the districts though not by all farmers, an indication that these are important source 
of agricultural information that can be strengthened by integrating with other sources.

Table 6. Organisation/information sources reported by farmers

\begin{tabular}{lcccc}
\hline & \multicolumn{2}{c}{ Percentage of farmers reporting from each farmer group } \\
\cline { 2 - 5 } Information source & $\begin{array}{c}\text { Akukuruantu } \\
\text { farmers' group } \\
\text { (total } \mathbf{n}=\mathbf{3 3})\end{array}$ & $\begin{array}{c}\text { Nyakoi } \\
\text { farmers' group } \\
\text { (total } \mathbf{n}=\mathbf{4 0})\end{array}$ & $\begin{array}{c}\text { Ajuko farmers' } \\
\text { group } \\
\text { (total n }=\mathbf{3 0})\end{array}$ & $\begin{array}{c}\text { Awasi farmers' } \\
\text { group } \\
\text { (total n= 46) }\end{array}$ \\
\hline Community/neighbours & 100 & 87.5 & 100 & 97.8 \\
Makerere University & 100 & 0 & 0 & 0 \\
NARO & 100 & 37.5 & 23.3 & 4.5 \\
LEAD USAID & 69.7 & 0 & 16.7 & 23.9 \\
NAADS/Government extension & 100 & 5.0 & 40 & 39.1 \\
CIP & 100 & 0 & 0 & 0 \\
NUSAF & 100 & 100 & 43.3 & 0 \\
UNDP & 0 & 100 & 0 & 0 \\
P'KWII & 0 & 55.0 & 0 & 0 \\
FAO & 0 & 0 & 100 & 73.9 \\
TPO & 0 & 0 & 20 & 100 \\
AFRICARE & 0 & 0 & 30 & 100 \\
CCF & 0 & 0 & 46.7 & 0
\end{tabular}

NARO; National Agricultural Research Organisation, NAADS; National Agricultural Advisory Services, CIP International potato centre (Centre international de la Papa), NUSAF: Northern Uganda Social Action Fund, UNDP: United Nations Development Programme, P'KWII: Popular knowledge women's' initiative, FAO Food and Agricultural Organisation, TPO Trans-cultural Psychosocial Organisation, AFRICARE, and CCF: Christian Children Fund.

\section{Discussion}

\subsection{Finger Millet Production Constraints in Selected Districts of Eastern Uganda}

In the current study, farmers identified high labour costs as the leading constraint to finger millet production. This finding is consistent with earlier studies carried out by Okwadi (2007), Kidoido et al. (2002), and Tenywa et al. (1999), in which farmers had earlier on pointed out labour costs as a major constraint to finger millet production. This mainly occurred because of the finger millet seed size which required very fine seedbed, and with over $95 \%$ of the farmers planting through broadcasting, it makes weeding and harvesting difficult.

The major biotic stress reported across all the districts was finger millet blast disease, with some reports of insect pests as in Kumi district, and occasionally the notorious and voracious Quelea quelea birds. This study revealed the persistence of the blast disease problem in finger millet production which has shown an increasing trend both in terms of incidence and severity over the years as evidenced by farmers' responses and susceptibility by cultivars which were otherwise initially resistant. In Bukedea and Kumi, the prevalence was reported to be exceptionally higher compared to Kaberamaido. The increase in prevalence over the years could be due to emergence of new races, recycling of infested seed and accumulation of inoculum through crop debris, volunteer crops and weeds. Whilst the reported low prevalence in Kaberamaido compared to the other two districts could point to longer fallow periods in rotations affordable in Kaberamaido since the household land holdings were higher, a difference in pathogen races and probably early selection and seed treatment by the Kaberamaido farmers.

\subsection{Farmers' Varietal Preference in Finger Millet}

In terms of preference for new finger millet cultivars, farmers who participated in this study preferred high grain yield, brown seed colour, compact head shape, tolerance to blast disease, high tillering ability, moderate plant height $(1 \pm 0.2 \mathrm{~m})$, early maturity, tolerance to shattering and ease of threshing without compromising the attributes preferred in the farmers' landraces. The major preferred varieties were Eserait and Etiyo in Kumi, 
Etiyo and Pese 1 in Bukedea, and Otunduru in Kaberamaido. Brown seed colour was preferred because it blends well with dry cassava chips to produce flour that is used for making local bread (Kwon or Atap) and has high malting quality for local brew as was also reported by Salasya et al. (2009). This probably indicates that the main use of finger millet in the study areas is for food (both local bread and porridge) and making local brew. It was also pointed out that reddish - brown grain colour was more preferred in the market and fetched higher prices compared to other grain colours. In addition, bird damage was reported to be less on the brown and dark coloured grains than the whitish coloured grains. In these communities therefore, brown-grained finger millet cultivars are important as food and nutrition security crop and for cash as well. Grain colour therefore is associated with its utility value as was also pointed out by Oduori and Kanyenji (2007), and hence has influence on the market value of the crop. Darker grain colours were also associated with low blast incidence and/or severity and less bird damage probably due to association with tannins. White and light-grained genotypes were reported by Seetharam and Ravikumar (1993) to have highly significant higher protein and lower phenols and tannins while brown-grained genotypes had relatively less protein with high phenols and tannins. Their findings suggested that in general, white-grained genotypes were more susceptible than brown and dark-grained types to blast disease.

Compact or fisted head shape was associated with higher grain yield, less shattering, blast disease tolerance and limited bird damage; making it a highly preferred trait. Cultivars with compact head shape ensured the farmer of yield in situations of high blast occurrence and serious bird damage. The high yield still ensured that there was enough food at the farmers' household and surplus for sale. Early maturing cultivars on the other hand were associated with drought escape, early relief for hunger, and minimizing crop loss through disease escape especially if sowing was done early (Wanyera, 2007b). This was particularly observed in Kumi with shorter rainy periods compared to Kaberamaido where drought seemed not to be important and their most preferred variety was a long duration cultivar. Another factor for the seemed preference of a longer duration cultivar was because of lack of short duration cultivars available in Kaberamaido. There has however, been an effort (after the survey) to introduce Seremi 2, a short duration cultivar, with relatively high yield to Kaberamaido district.

On plant height; farmers preferred medium plants heights because of ease of harvest as also observed by Wanyera (2007a), and reduced lodging which occurs in taller plants. On the other hand, as pointed out by Kimani, Tongoona, Derera, and Nyende (2011) on rice very short varieties are near the ground and would increase damage due to rodents, water splash, ground walking birds and termite damage on grains. They also observed that birds found it easy to perch on the shorter varieties because they were relatively stronger.

\subsection{Farmers' Knowledge on Finger Millet Blast Disease}

Basing on this study, a considerable proportion of the farmers had limited or no idea about the disease, its cause(s) and coping mechanism. The majority of the farmers however, recognised the disease but associated it with other causes like witch-craft and drought and had no name for it; only a very small fraction were aware of the disease and had a name for it. In Kumi and Bukedea it was called ejetele whereas there was no name given to it in Kaberamaido. On the occurrence of blast disease symptoms farmers in all locations reported that symptoms were on the increase over the years and pointed out the most susceptible and tolerant cultivars. Farmers in Kumi pointed out that only Seremi 2 was tolerant while in Kaberamaido, Otunduru was the most tolerant cultivar. It was noted in Kumi and Bukedea that Pese 1, which was very tolerant, was now showing more symptoms of the disease than in earlier years. Farmers also reported that susceptibility was higher in open headed cultivars compared to fisted/compact headed cultivars similar to findings of Takan et al. (2004). The cause and spread of the disease was not known among the farmers/farmers' groups; creating a serious lack of awareness of the pathogen, pathogen development and spread, and therefore no control mechanisms were reported. This is an indication of the need for more research and adequate extension services to manage the disease. In the short term, a number of genotypes are to be evaluated in different environments of the finger millet growing areas to: a) study the pathogen, $b$ ) identify sources of resistance and c) increase the resistant materials with farmer preferred attributes and channel them to the farmers through different seed uptake pathways.

\subsection{Sources of Agricultural Information}

Major access to information was through farmer to farmer contrary to what Mhike, Okori, Kassie, Magorokosho, and Chikobvo (2012) found for drought tolerant maize varieties in Zimbabwe. Information access through farmer to farmer ranged from $87.5 \%$ of the farmers surveyed to $100 \%$ for the different farmer groups. This means that involvement of lead farmers or groups in breeding and dissemination activities may be a successful option. Government agencies were reported across all the other groups as sources of information. These were the government extension system and the national research organisation but at varying levels (Table 6). Non 
governmental organisations were also identified, but they tended to be localised in particular areas of operation though with high levels of coverage in those particular areas than the government agencies. Inspite of the visible information exchange among the farmers, lack of information was still apparent on finger millet improved varieties, blast disease and other associated finger millet production technologies. This has resulted in farmers growing their old varieties with low yields due to lack of options. Strengthening information dissemination would therefore involve breeding in partnership with farmers, government extension and the private sector.

\section{Conclusion and Implication for Breeding}

This study demonstrated and revealed the importance of finger millet in Uganda as food, food and nutrition security, and an income crop. The major constraints included among others: high labour requirements, biotic stress factors principal among them finger millet blast disease; declining soil fertility, drought and land shortage in some areas. Farmers in the study area showed preference for high grain yield, brown seed colour, compact ear shape, tolerance to blast disease, high tillering ability, medium plant height of $1 \pm 0.2 \mathrm{~m}$, early maturity, tolerance to shattering and ease of threshing without compromising the attributes preferred in their landraces. The study also revealed that a considerable proportion of the farmers had limited or no idea on finger millet blast disease, its causes and control strategies. The majority of the farmers recognised the disease but associated it with other causes; this therefore calls for more research and adequate extension services to manage the disease. As a short term management strategy, a number of genotypes with considerable resistance are to be evaluated in the different environments of the finger millet growing areas to: a) study the pathogen, b) identify sources of resistance and c) increase the resistant materials with farmer preferred attributes and channel them to the farmers through different seed uptake pathways. In the long term, development of blast disease resistant varieties through breeding is to be pursued. This approach has been proved more applicable to the small-scale resource poor farmers, the majority of whom are finger millet growers in Uganda. There is also limited involvement of the private sector in the finger millet improvement and seed system, a revelation that requires the strengthening and support of current players, that is, the private sector, NGOs and government extension system coordinated by the public sector breeding program for efficient development and delivery of seed and associated technologies to the finger millet farmers.

\section{References}

Banziger, M., \& Cooper, M. (2001). Breeding for low input conditions and consequences for participatory plant breeding: examples from tropical maize and wheat. Euphytica, 122, 503-519. http://dx.doi.org/10.1023/A:1017510928038

Banziger, M., Edmeades, G. O., Beck, D., \& Bellon, M. (2000). Breeding for drought and nitrogen stress tolerance in maize: From theory to practice. Mexico, D.F.: CIMMYT.

Bedis, M. R., Ganvir, B. N., \& Patil, P. P. (2006). Genetic variability in finger millet. Journal of Maharashtra Agricultural University, 31, 369-370.

Chambers, R. (1994). Participatory Rural Appraisal (PRA): Challenges, potentials and paradigm. World Development, 22, 1437-1454. http://dx.doi.org/10.1016/0305-750X(94)90003-5

Daniel D., Parveviet, J., Almekinders, C., \& Thiele, G. (2007). Farmers' participation and breeding for durable disease resistance in the Andean region. Euphytica, 153, 385-396. http://dx.doi.org/10.1007/s10681-006-9165-9

Dorward, P., Craufurd, P., Marfo, K., Dogbe, W., \& Bam, R. (2007). Improving participatory varietal selection process: Participatory varietal selection and the role of informal seed mechanisms for upland rice in Ghana. Euphytica, 155, 315-327. http://dx.doi.org/10.1007/s10681-006-9333-y

Fakrudin, B., Kulkani, R. S., Shashidhar, H. E., \& Hittalmani, S. (2004). Genetic diversity assessment of finger millet, Eleusine coracana (Gaertn), germplasm through RAPD analysis. Biodiversity International Newsletter, 138, 50-54.

Islam, M. R., Salam, M. A., Bhuiyan, M. A. R., Rahman, M. A., \& Gregorio G. B. (2008). Participatory variety selection for salt tolerance. International Journal of BioResources, 4, 21-25.

Kidoido, M. M., Kasenge, V., Mbowa, S., Tenywa, J. S., \& Nyende, P. (2002). Socio-economic factors associated with finger millet production in eastern Uganda. African Crop Science Journal, 10, 111-120. http://dx.doi.org/10.4314/acsj.v10i1.27561

Kimani, J. M., Tongoona, P., Derera, J., \& Nyende, A. B. (2011). Upland rice varieties development through participatory plant breeding. Asian Research Publishing Journal, 6, 39-49. 
Mhike, X., Okori, P. Kassie, G. T., Magorokosho, C., \& Chikobvo, S. (2012). An appraisal of farmer variety selection in drought prone areas and its implication to breeding for drought tolerance. Journal of Agricultural Sciences, 4, 27-43.

Ministry of Agriculture Animal Industry and Fisheries [MAAIF]. (2008). Facts and Figures for the Agricultural Sector 2008 (pp. 48-49). An Annual Report of Agricultural Planning Department, Entebbe, Uganda.

Oduori, C. O. A., \& Kanyenji, B. (2007). Finger millet in Kenya: Importance, Advances in R \& D, Challenges and opportunities for improved production and profitability. Facilitating the promotion of improved and blast resistant finger millet varieties to enhance production. In M. A. Mgonja, J. M. Lenne, E. Manyasa \& S. Sreenivasaprasad (Eds.), Proceedings of the first international finger millet stake-holders workshop, projects R8030 \& 8445, UK Department for international development - crop protection programme held on $13^{\text {th }}-14^{\text {th }}$ September 2005 at Nairobi (pp. 10-22).

Okwadi, J. (2007). Importance and characteristics of finger millet processing Uganda. In M. A. Mgonja, J. M. Lenne, E. Manyasa \& S. Sreenivasaprasad (Eds.), Proceedings of the first international finger millet stake-holders workshop, projects R8030 \& 8445, UK Department for international development - crop protection programme held on $13^{\text {th }}-14^{\text {th }}$ September 2005 at Nairobi (pp. 102-111).

Salasya, B., Oduori, C., Ambitsi, N., Onyango, E., Oucho, P., \& Lumuli, J. (2009). The status of finger millet production in western Kenya. African Crop Science Conference Proceedings, 9, 719-723.

Seetharam, A., \& Ravikumar, R. L. (1993). Blast resistance in finger millet. Its inheritance and biochemical nature. In K. W. Riley, S. C. Gupta, A. Seetharam \& J. Mushonga (Eds.), Advances in small millet (pp. 449-465). New York international science publisher, New York City, New York.

SPSS 20.0, SPSS Inc. (2011). Headquarters, 233 S. Wacker Drive, $11^{\text {th }}$ floor Chicago, Illinois, USA.

Takan, J. P., Akello, B., Esele, P., Manyasa, E. O., Obilana, A., Audi, P. O., ... Sreenivasaprasad, S. (2004). Finger millet blast pathogen diversity and management in East Africa: a summary of project activities and outputs. International Sorghum and Millets Newsletter, 45, 66-69.

Tenywa, J. S., Nyende, P., Kidoido, M., Kasenge, V., Oryokot, J., \& Mbowa, S. (1999). Prospects and constraints of finger millet production in eastern Uganda. African Crop Science Journal, 7, 569-583. http://dx.doi.org/10.4314/acsj.v7i4.27751

Thiele, G., Gardner, G., Torrez, R., \& Gabriel, J. (1997). Farmer involvement in selecting new varieties: Potatoes in Bolivia. Experimental Agriculture, 33, 275-290. http://dx.doi.org/10.1017/S0014479797003098

Upton, M. (1987). African Farm Management. New York. Cambridge University Press. U.S.A.

Wanyera, N. M. W. (2007a). Finger millet (Eleusine coracana (L.) Gaertn) in Uganda. In M. A. Mgonja, J. M. Lenne, E. Manyasa \& S. Sreenivasaprasad (Eds.), Proceedings of the first international finger millet stake-holders workshop, projects R8030 \& 8445, UK Department for international development - crop protection programme held on $13^{\text {th }}-14^{\text {th }}$ September 2005 at Nairobi (pp. 1-9).

Wanyera, N. M. W. (2007b). Facilitating the promotion of improved and blast resistant finger millet varieties to enhance production. In M. A. Mgonja, J. M. Lenne, E. Manyasa \& S. Sreenivasaprasad (Eds.), Proceedings of the first international finger millet stake-holders workshop, projects R8030 \& 8445, UK Department for international development - crop protection programme held on $13^{\text {th }}-14^{\text {th }}$ September 2005 at Nairobi (pp. 66-67).

\section{Copyrights}

Copyright for this article is retained by the author(s), with first publication rights granted to the journal.

This is an open-access article distributed under the terms and conditions of the Creative Commons Attribution license (http://creativecommons.org/licenses/by/3.0/). 